Rapp. Grønlands geol. Unders. 99, 33-42 (1980)

\title{
CAMBRIAN STRATIGRAPHY IN PEARY LAND, EASTERN NORTH GREENLAND
}

\section{J. R. Ineson and John S. Peel}

Cambrian strata in southern Peary Land occur in a continuous outcrop from J. P. Koch Fjord and Adams Gletscher in the west to Independence Fjord in the east (fig. 15), forming a conspicuous rampart on the northern side of Wandal Dal. The Lower Cambrian sequence around Jørgen Brønlund Fjord has previously been described by Troelsen (1949), Jepsen (1971) and Christie \& Peel (1977), who recorded possible Cambrian dolomites of the Portfjeld Formation succeeded by the clastic Buen Formation and the dolomitic Brønlund Fjord Formation, both of Early Cambrian age. Troelsen (1956) and Christie \& Ineson (1979) have discussed a similar sequence which occurs near G.B. Schley Fjord in eastern Peary Land (fig. 1).

Peel (1979) built on reconnaissance by Dawes (1976) when describing a much more complete Cambrian sequence, including Middle and Upper Cambrian, from the Adams Gletscher region. The largely carbonate sequence which occurs above the Buen Formation

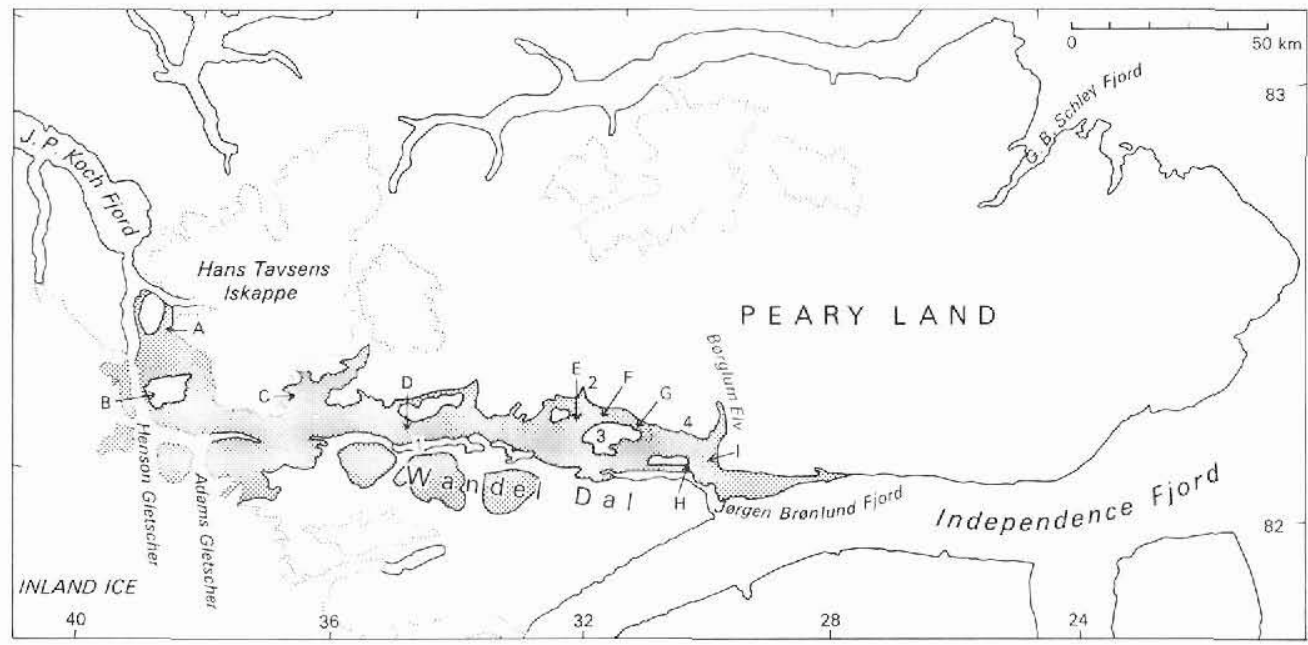

Fig. 15. Cambrian outcrops and localities in the J. P. Koch Fjord to Independence Fjord area of southern Peary Land. The Cambrian outcrops (shaded) are concentrated along the northern side of Wandel Dal and are taken from a preliminary geological map of the region published in Rapp. Gronlands geol. Unders. 88 (1979). Sections at localities A -I represented by figs 16 and 17. Localities are at: A, east of J. P. Koch Fjord; B, Henson Gletscher; C, east of Hans Tavsens Iskappe; D, Øvre Midsommersø; E, F, Sæterdal; G, Frysefjeld; H, Jørgen Brønlund Fjord, section locality of Troelsen (1949); I, Børglum Elv, section of Christie \& Peel (1977).

Place names: 1. Øvre Midsommersø; 2. Sæterdal; 3. Frysefjeld; 4. Paralleldal. 


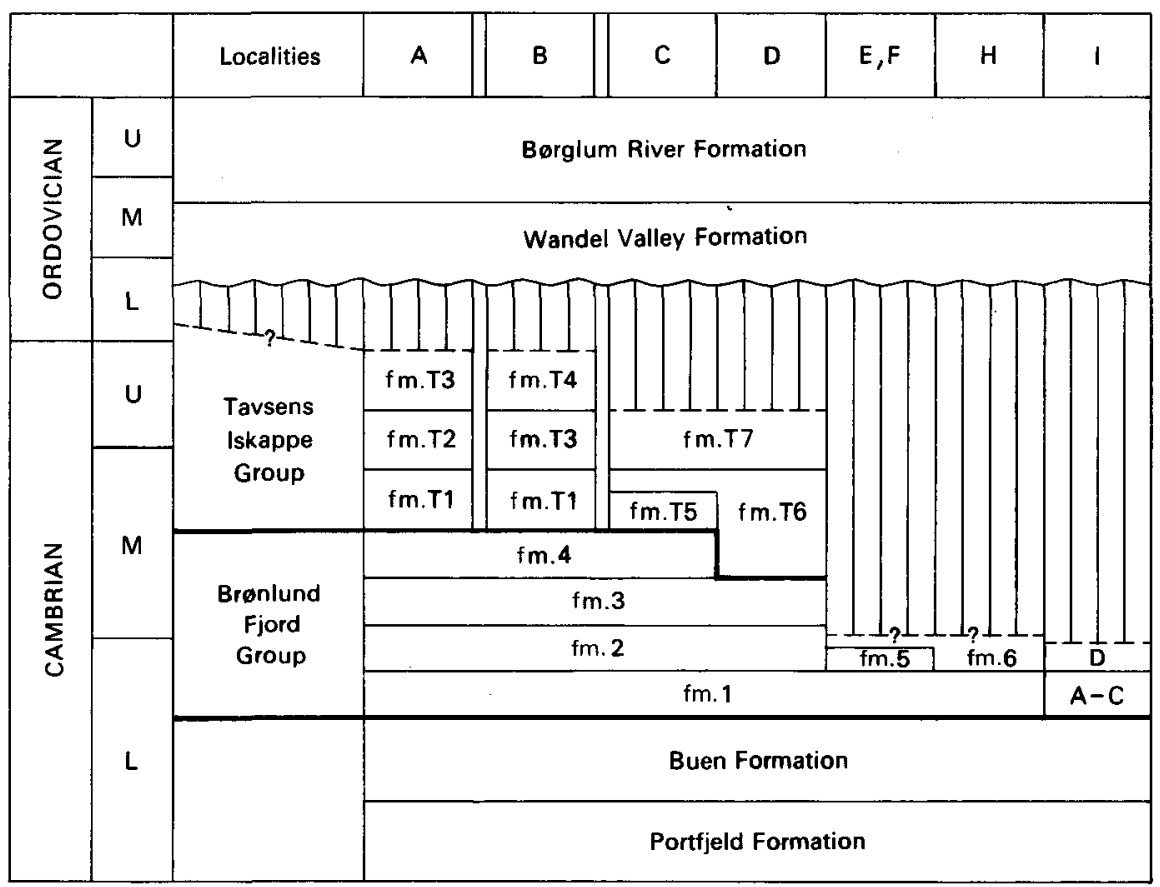

Fig. 16. Cambrian stratigraphy in southern Peary Land. Section localities are shown in fig. 15. A - D in column I refer to members of the former Brønlund Fjord Formation of Christie \& Peel (1977).

at Adams Gletscher was divided, by Peel, into two lithostratigraphic groups. The lower group, termed the Brønlund Fjord Group, included four formations recognised as being partly equivalent to the previously described Brønlund Fjord Formation of the Jørgen Brønlund Fjord region. The latter formation was recognised as comprising two of the new formations of the Brønlund Fjord Group, so use of the name at formational level was discontinued. The overlying Tavsens Iskappe Group was subdivided, by Peel, into four formations in the type area immediately east of J. P. Koch Fjord (A in fig. 15). Difficulties associated with correlating these four formations with sections away from the type area were noted, but not resolved at that time.

Field work during 1979 permitted the establishment of a correlation between the two previously described sequences, in the Jørgen Brønlund Fjord and Adams Gletscher regions respectively and hence the formulation of a regionally applicable stratigraphic nomenclature (figs 16 and 17). The scheme is briefly outlined below, paying particular attention to modifications in the stratigraphy proposed by Peel (1979).

\section{Portfjeld Formation}

This formation was defined by Jepsen (1971) and subsequently discussed by O'Connor (1979) and Peel (1979). Samples collected from the lower part of the formation during 1978, from near the western end of Øvre Midsommersø (fig. 15, locality D) have yielded 


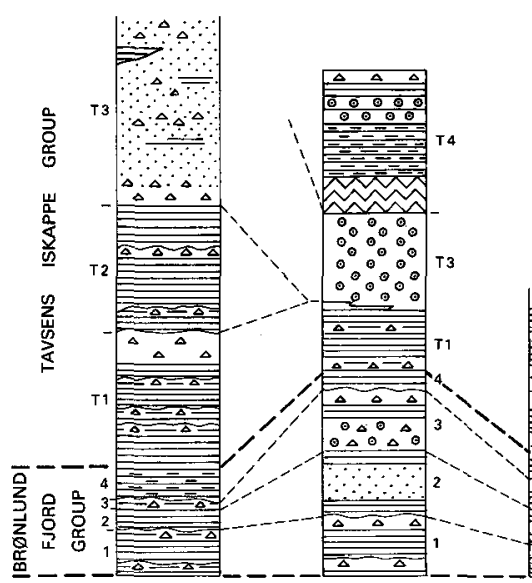

A

B

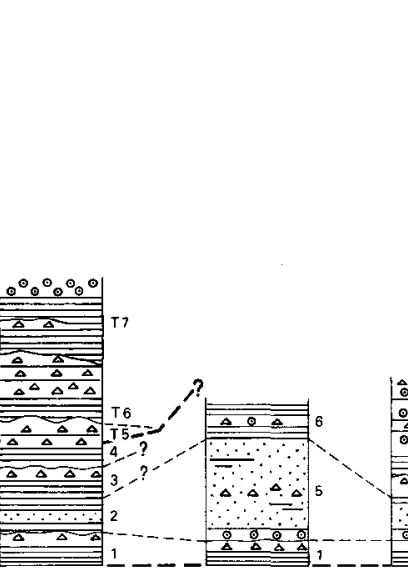

C

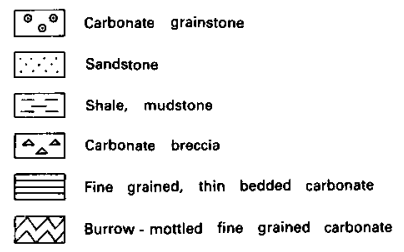

Fig. 17. Sedimentology and formational relationships of the Brønlund Fjord and Tavsens Iskappe Groups. Sections at localities A-H are localised in fig. 15. 1-6 formations of the Brønlund Fjord Group; T1-T7 formations of the Tavsens Iskappe Group.

coil-like tubular phosphatic microfossils (Peel, 1980). The fossils, and the stratigraphic position of the Portfjeld Formation below the undoubtedly Early Cambrian Buen Formation, indicate a similar Early Cambrian age for the Portfjeld Formation.

\section{Buen Formation}

Palmer \& Peel (1979) considered that olenellids, from just above the middle of the Buen Formation, indicated a medial Early Cambrian age. Lower beds of the formation and the underlying Portfjeld Formation may, consequently, be as old as earliest Early Cambrian.

Strata in the G. B. Schley Fjord region (fig. 15) described by Christie \& Ineson (1979) and correlated with the Buen Formation were termed the Schley Fjord shale by Troelsen (1956). It is not proposed to discuss which of these two lithostratigraphic names is to be preferred, at this time.

\section{Bronlund Fjord Group}

This group was erected by Peel (1979) who recognised four un-named formations in the Adams Gletscher region of south-western Peary Land (figs 15-17, locality A). No precise correlation with the Jørgen Brønlund Fjord sequence was attempted at that time, although Peel (1979, p. 32) commented that the Brønlund Fjord Formation of Troelsen (1949) and Christie \& Peel (1977) was equivalent to the two lowest formations at Adams Gletscher. Field work during 1979 has caused this opinion to be revised, and the former Brønlund Fjord Formation is now subdivided into formation 1 of Peel (1979) and a new formation (formation 6) of the Brønlund Fjord Group (figs 15-17, locality $\mathrm{H}$ ). 
The fourfold division of the Brønlund Fjord Group, proposed by Peel, can only be recognised to the west of Øvre Midsommersø. To the east of the lake, the group is divided into three formations (figs 15-17, localities E-F). Formation 1 continues to be recognisable as a distinctive bluff-forming feature and can be traced to Jørgen Brønlund Fjord, where it corresponds to members $\mathrm{A}, \mathrm{B}$ and $\mathrm{C}$ of the Brønlund Fjord Formation of previous usage (Christie \& Peel, 1977). However, formations 2, 3 and 4 of the Brønlund Fjord Group cannot be recognised in these eastern outcrops and it is necessary to propose two additional formations in this area, referred to below as formations 5 and 6. Formation 5 has previously been referred to by Palmer \& Peel (1979).

\section{Formation 1}

This is a generally pale-weathering, dolomite unit which is conspicuous throughout the area on account of its cliff-forming outcrop above the recessive Buen Formation. At Henson Gletscher the formation is overlain by dark, recessive carbonates of formation 2, but these are gradually replaced by pale sandstones and dolomites of formation 5 in the øvre Midsommersø to Sæterdal area (figs 15-17, locality E).

Formation 1 is equivalent to members $\mathrm{A}, \mathrm{B}$ and $\mathrm{C}$ of the Brønlund Fjord Formation of Christie \& Peel (1977) at Børglum Elv (fig. 15) , and is here overlain by formation 6, which includes member D of Christie \& Peel (fig. 16, locality I).

Fossils are only known from the basal member of formation 1. Palmer \& Peel (1979) noted Bonnia, Calodiscus and fragments of Wanneria indicative of a late Early Cambrian age. This basal member is discussed elsewhere in this report by Frykman.

\section{Formation 2}

The bituminous dolomites, shales and limestones of formation 2 form a characteristic, dark, recessive stripe between the cliff-forming formations 1 and 3 in the Henson Gletscher region (fig. 18). Towards the south and east, thin beds of pale dolomitic sandstone become conspicuous as the formation interdigitates with formation 5.

Formation 2 is richly fossiliferous, yielding well preserved faunas of trilobites, molluscs and brachiopods. Collections from the 1978 field season suggested that most of the formation was of Middle Cambrian age. However, additional collections with olenellids, made during 1979, indicate that more than half the formation is of late Early Cambrian age. Palmer \& Peel (1979) recorded Olenellus, Bonnia, Ogygopsis and a distinctive species of Kootenia in the lower part of the formation. Agnostid dominated faunas from the highest beds indicate a medial Middle Cambrian age.

\section{Formation 3}

Formation 3 consists, mainly, of Middle Cambrian nodular limestones and dolomitised limestones in the Adams Gletscher region, although these are partially replaced by crossbedded grainstones in more southerly outcrops. A sheet of dolomite breccia caps most sections. 


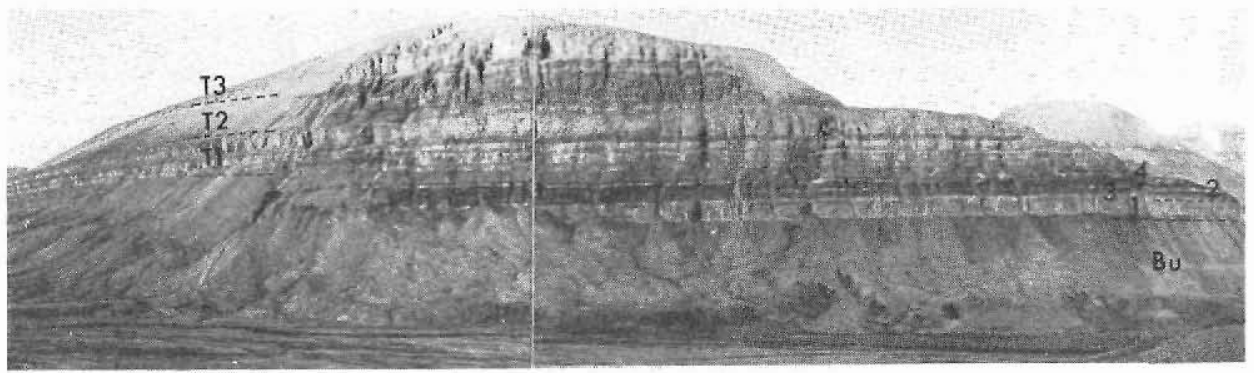

Fig. 18. Cambrian sequence at locality A (figs 15-17), east of J. P. Koch Fjord, viewed from south-east. Height of section is approximately $850 \mathrm{~m}$. Bu, Buen Formation; 1-4, Brønlund Fjord Group, formations 1-4; T1-T3, Tavsens Iskappe Group, formations T1-T3.

\section{Formation 4}

Grey-weathering, soft grey shales and lenticular limestones of this formation yield trilobites of medial Middle Cambrian age (Palmer \& Peel, 1979). At locality B in fig. 15 Peel (1979, p. 34) considered that the upper two thirds of this formation were composed of parallel bedded dolomites. However, these dolomites are now referred to formation T1 of the overlying Tavsens Iskappe Group.

\section{Formation 5}

This formation, previously referred to by Palmer \& Peel (1979), overlies conformably formation 1 and commonly forms recessive slopes below the cliff-forming dolomites of formation 6 . It is dominated by pale cream, fine-grained, dolomitic sandstones in parallel, medium to thick beds, interbedded with dark, bioturbated, silty sandstones and siltstones. Laminated and glauconitic bioclastic dolomites occur in the lower few metres with rare, slumped carbonate intervals higher in the formation. Formation 5 reaches its maximum development of about $120 \mathrm{~m}$ on the north side of Sæterdal (fig. 15, locality E) but thins rapidly to the south and east. East of Frysefjeld, this clastic interval is not represented and the Brønlund Fjord Group comprises formation 1 and 6 (figs 15-17, localities G, H).

To the west of Sæterdal exposure is broken, but it appears that formation 5 is the lateral equivalent of formation 2, in which similar sandstones are subordinate to fetid, laminated, dark dolomites and limestones. The proportion of sandstone in formation 2 increases to the south and east and, for mapping purposes, the boundary between the two formations is drawn near Øvre Midsommersø (fig. 15). Thus, formation 2 occurs to the west of this area, formation 5 to the east.

A diverse fauna of trilobites and brachiopods, indicative of a late Early Cambrian age, has been recorded from formation 5 at Sæterdal by Palmer \& Peel (1979). 


\section{Formation 6}

The recessive clastics of formation 5, which occur in the Sæterdal to Paralleldal area, are overlain by bluff-forming, pale orange and yellow-weathering dolomites of formation 6 . This formation is itself overlain unconformably, by the Wandel Valley Formation of late Early to Middle Ordovician age. Formation 6 is lithologically very variable, with units of thick, bioclastic and oolitic dolomite grainstones, often with associated slumped intervals, passing northwards into darker, thin-bedded, graded and laminated dolomites and interbedded massive breccia sheets. Formation 6 reaches a maximum thickness of $140 \mathrm{~m}$ on the east side of Sæterdal (figs 15-17, locality F), but thins eastwards into Børglum Elv where it includes member D of the former Brønlund Fjord Formation of Christie \& Peel (1977). To the west, along Sæterdal, the formation becomes poorly defined in broken terrain and apparently pinches out at the unconformity with the overlying Wandel Valley Formation. This westwards thinning accompanies the gradual thickening of the subjacent formation 5 .

Formation 6 yields archaeocyathids, poorly preserved trilobites and brachiopods of uncertain, though probable Early Cambrian age.

\section{Tavsens Iskappe Group}

Peel (1979) gave this name to strata which occur between the Brønlund Fjord Group and the sub-Wandel Valley Formation unconformity in the J. P. Koch Fjord - Adams Gletscher region, on the western side of Hans Tavsens Iskappe (fig. 15, locality A). Four formations were recognised and a total thickness of about $900 \mathrm{~m}$ suggested. No satisfactory correlation with the other areas of outcrop of the Tavsens Iskappe Group could be given at that time.

Field work during 1979 resulted in a slight re-definition of the formations proposed by Peel (1979) and a reduction in the estimated thickness of the group from $900 \mathrm{~m}$ to about 700 $\mathrm{m}$. Formations 1 and 2 are maintained (as formations T1 and T2) but formations 3 and 4 are combined to form a single unit, the formation T3 of present usage (figs 16 and 17 , locality A). The changes reflect recognition of the prograded character of the upper beds of the group (Ineson, this report). In addition, a correlation with sections near the junction of Adams Gletscher and Wandel Dal (figs 15-17, locality B) originally described by Dawes (1976) has now been established. An additional formation (formation T4) is recognised here (fig. 18). The thick Tavsens Iskappe Group sequence, on the eastern side of Hans Tavsens Iskappe (figs $15-17$, locality $C$ ), is subdivided into three additional formations, formations T5 - T7, which can only be tentatively correlated with formations in the Adams Gletscher J. P. Koch Fjord region.

Peel (1979) arbitrarily drew the Middle Cambrian - Upper Cambrian boundary at the base of the Tavsens Iskappe Group. Closer examination of trilobites from near the base of formation T2 prompted Palmer \& Peel (1979) to place the boundary within the lower beds of this formation. Formation $\mathrm{T} 1$ was at that time considered unfossiliferous, although several collections were made during 1979. Samples from near the top of the Tavsens Iskappe Group, at locality 2 of Peel (1979, fig. 9), north of the present locality A (fig. 15) have yielded scattered, as yet undetermined conodonts, tentatively presumed to indicate a latest Cambrian or younger age.

Formations described below have been given the prefix $\mathrm{T}$ to avoid confusion with formations described by Peel (1979). 


\section{Formation T1}

This formation of limestones and dolomites forms step-like cliffs above the recessive formation 4 of the Brønlund Fjord Group. In northerly exposures (locality A in figs 15-17) the formation is characteristically composed of thick, pale-weathering dolomite breccia sheets interbedded with darker thin-bedded dolomites and argillaceous, micritic limestones which are commonly nodular and locally slumped. The upper boundary of the formation in the north is defined by the hummocky upper surface of a $40 \mathrm{~m}$ thick sheet of pale dolomite breccia which is overlain by dark thin-bedded dolomites and limestones of formation $\mathrm{T} 2$. Formation T1 is approximately $175 \mathrm{~m}$ thick at locality A but thins to less than half this thickness at locality B, to the south. In this southerly area, formation $\mathrm{T} 1$ is composed of thin-bedded, dark grey dolomites overlying a $30 \mathrm{~m}$ thick unit of pale-weathering slumped, laminated dolomites interbedded with 1 to $3 \mathrm{~m}$ thick breccias. At locality B (figs 15-17), formation $\mathrm{T} 1$ is overlain by pale oolitic dolomites of formation $\mathrm{T} 3$ as a result of the northerly prograding nature of the sediments (see Ineson, this report).

Rich faunas of agnostids of Middle Cambrian age have been obtained from thin-bedded recessive limestones, near the middle of the formation, in northerly exposures.

\section{Formation T2}

This formation of dark recessive limestones, dolomites and shales is only recognisable in northern exposures, in the J. P. Koch Fjord area (figs 15-17, locality A). The formation rests on the undulating upper surface of formation $\mathrm{T} 1$ and is overlain by the bluff-forming, pale dolomite breccias, grainstones and sandstones of formation T3. At locality A, (fig. 18) the formation attains a thickness of $155 \mathrm{~m}$, but then it is reduced rapidly to the south so that the formation is absent at locality B, near the junction between Henson Gletscher and Wandel Dal.

Formation $\mathrm{T} 2$ is dominated by thin, wavy- to parallel-bedded laminated dark dolomites and limestones, with argillaceous partings. Thin sheets of slump breccia, up to $5 \mathrm{~m}$ in thickness, occur near the top and bottom of the formation.

Formation T2 is richly fossiliferous. Palmer \& Peel (1979) placed the Middle Cambrian Late Cambrian boundary at just above the base of the formation, where rich faunas of agnostid and other trilobites, molluses and brachiopods are conspicuous.

\section{Formation T3}

This formation includes both formations 3 and 4 of the Tavsens Iskappe Group sensu Peel (1979) and consists of a thick succession of pale-weathering, thick-bedded, cross-stratified carbonate grainstones, dolomitic quartz-sandstones and quartzites. Slumped intervals and breccia sheets are widespread. In the excellent exposures along J. P. Koch Fjord and Henson Gletscher (fig. 19) individual units within formation T3 are frequently seen to be lenticular and to thin out, northwards, into darker-weathering carbonates. Wedges of these darker, thin-bedded silty dolomites are commonly intercalated within the pale units emphasising northerly depositional dips up to 20 degrees.

The top of formation T3 is not seen in northerly exposures where dolomites of the Wandel Valley Formation overlie unconformably the Tavsens Iskappe Group. At least $400-420 \mathrm{~m}$ 


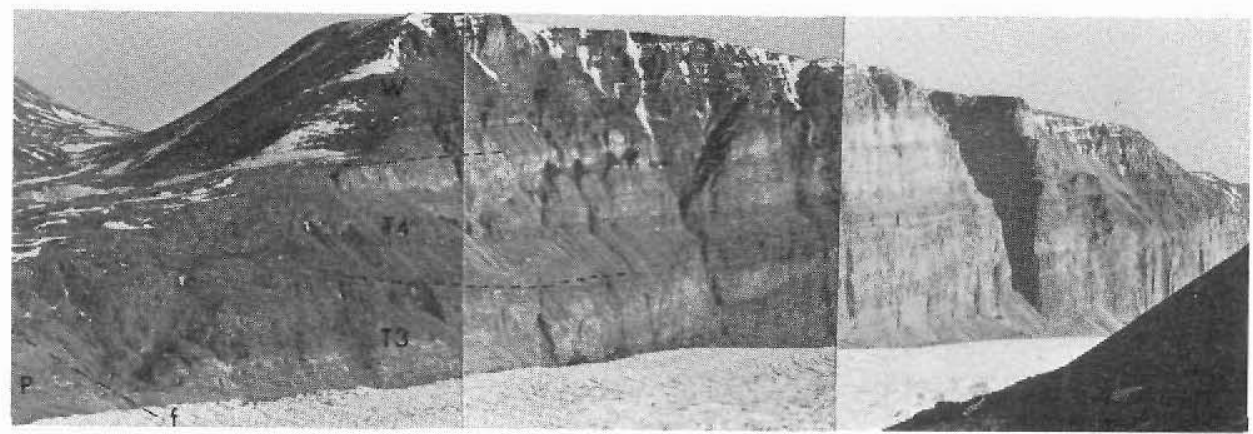

Fig. 19. Cambro-Ordovician strata at Henson Gletscher (locality B, figs 15-17), viewed from north-west. Height of section is approximately $800 \mathrm{~m}$. Formations T3 and T4 of the Tavsens Iskappe Group, overlain by the Wandel Valley Formation (W) are faulted (ff) against the Portfjeld Formation (P).

of formation $\mathrm{T} 3$ are preserved at locality $\mathrm{A}$, where the sequence is dominated by cross-bedded quartzites, sandy dolomites and thick sandstone-dolomite breccias. Dark wedges of thinly bedded silty dolomite thicken northwards.

In more southerly outcrops (figs 15-17, locality B) formation T3 consists of approximately $120 \mathrm{~m}$ of pale oolitic dolomite grainstones which are overlain by the argillaceous, bioturbated, mottled dolomites of formation T4 (fig. 19).

Fossils are rare in formation T3. Monoplacophorans resembling Proplina and hyperstrophic onychochilacean gastropods from locality A support the general Late Cambrian age which is suggested on stratigraphic grounds. Simple conodonts have been recovered from one of the dark wedges near the top of the known sequence, north of locality $\mathrm{A}$, and may indicate a latest Cambrian or, possibly, even earliest Ordovician age.

\section{Formation T4}

This formation is apparently of very restricted distribution, and is only well exposed along the sides of Henson Gletscher at locality B (figs 15 and 19). The boundary with the underlying formation $\mathrm{T} 3$ is seemingly sharp and the formation is overlain unconformably by pale dolomites of the Wandel Valley Formation. Owing to the largely inaccessible exposures, the suggested thickness of approximately $170-200 \mathrm{~m}$ is only an estimate. About $30 \mathrm{~m}$ of medium- to thick-bedded, burrowed, mottled dolomite at the base of the formation are overlain by a prominent dark bed of stylolitic, intensely bioturbated dolomite about $10 \mathrm{~m}$ thick. Overlying, thinly bedded, flaggy dolomites and green silts are succeeded by about 100 $\mathrm{m}$ of pale dolomites with in places thin, greenish siltstones. The dolomites are bioturbated or cross-bedded but several thin $(20-50 \mathrm{~cm})$ units of fine algal laminated dolomitic limestones are conspicuous.

The relationship between formation $\mathrm{T} 4$ and the sequence at locality $\mathrm{A}$ is uncertain. The prograded strongly diachronous nature of the Tavsens Iskappe Group (Ineson, this report) 
suggests that formation $\mathrm{T} 4$ is older than many of the rocks assigned to formation $\mathrm{T} 3$ at locality $\mathrm{A}$, despite the fact that $\mathrm{T} 4$ overlies $\mathrm{T} 3$ and is consequently younger than $\mathrm{T} 3$ at locality B.

\section{Formation T5}

Formations T5-T7 only occur to the east of Hans Tavsens Iskappe and can be only tentatively correlated with formations in the type area of the Tavsens Iskappe Group, which occur on the western side of the ice cap. At locality C (figs 15-17), formation T5 is a prominent, pale cream-weathering dolomite resting sharply on the recessive argillaceous limestones of formation 4 of the Brønlund Fjord Group. It is overlain by dark, recessive carbonates of formation T6. The upper boundary of the formation is often very irregular, causing variations in the thickness of T5 from 15 to $30 \mathrm{~m}$. Formation T5 is dominated by dolomite breccia, which is commonly composed of two distinct sheets between which are lenses of distorted, thinly bedded dolomite. The upper breccia sheet contains scattered house-sized blocks of pale, cross-bedded grainstones which protrude through the upper surface, producing the very irregular upper boundary of the formation. T5 can be mapped from Hans Tavsens Iskappe eastwards, but it peters out just to the west of Øvre Midsommersø.

Formation T5 is considered to be Middle Cambrian on account of its stratigraphic position between the Brønlund Fjord Group and the overlying formation T6, both of which yield Middle Cambrian trilobites. Its age and lithology suggest a tentative correlation with part of formation $\mathrm{T} 1$.

\section{Formation T6}

Recessive, dark grey- to yellowish-weathering carbonates of formation T6 lie on the irregular top of formation T5 and are themselves overlain by massive yellow-brown-weathering dolomites of formation T7. As noted above, T5 pinches out between Hans Tavsens Iskappe and Øvre Midsommers $\varnothing$ so that formation T6 directly overlies formation 4 of the Brønlund Fjord Group in the Øvre Midsommersø area (fig. 16, locality D). It thus becomes impractical, in this small area, to continue the division between T6 and formation 4 since the distinctive formation T5 is missing. Thus, in this area, the estimated $100 \mathrm{~m}$ of dark, recessive parallel-bedded limestones and dolomites, above formation 3 of the Brønlund Fjord Group and below formation T7 of the Tavsens Iskappe Group, are referred to formation T6 of the Tavsens Iskappe Group.

Formation T6 is composed of dark grey-weathering, thin-bedded dolomites and argillaceous, laminated, micritic limestones. Bedding varies from parallel to gently wavy. In places breccia sheets, up to $0.5 \mathrm{~m}$ thick, occur.

Middle Cambrian fossils may be locally abundant in formation T6. Lithologically, formation T6 is similar to formation T2 on the western side of Hans Tavsens Iskappe but, in view of its age, it most probably correlates with part of formation $\mathrm{T} 1$. 


\section{Formation $T 7$}

Formation $\mathrm{T7}$ (figs 16 and 17) is a variable, bluff-forming unit of pale, golden-brown-weathering dolomites which, northwards, become intercalated with lenticular units of dark, grey-brown bioturbated dolomites. At least $200 \mathrm{~m}$ of strata are estimated to be preserved under the unconformity with the overlying Wandel Valley Formation.

The lower half of the formation at locality $\mathrm{C}$ is dominated by thick breccia sheets, commonly containing huge blocks of dolomite grainstones, interbedded with thin-bedded, dark grey-brown dolomites. Laminated and bioturbated dolomites interbedded with the breccia sheets contain in places a scatter of ooliths. The upper part of the formation at locality $\mathbf{C}$ is composed of medium- to thin-bedded, stylolitic, pale cream or white dolomites, with a suggestion of cross-bedding. These pale dolomites thin northwards and are replaced by wedges of dark-weathering, grey-brown, medium-bedded, bioturbated dolomites.

The upper part of formation T7 resembles formation T3 to the west of Hans Tavsens Iskappe, and when the diachronous nature of the Tavsens Iskappe Group is considered, it could be an approximate correlative of this unit. The lower part of $\mathrm{T} 7$ is, lithologically, more similar to $\mathrm{T} 1$.

\section{References}

Christie, R.L. \& Ineson, J. R. 1979: Precambrian-Silurian geology of the G. B. Schley Fjord region, eastern Peary Land, North Greenland. Rapp. Grønlands geol. Unders. 88, 63-71.

Christie, R. L. \& Peel, J. S. 1977: Cambrian-Silurian stratigraphy of Børglum Elv, Peary Land, eastern North Greenland. Rapp. Grønlands geol. Unders. 82, 48 pp.

Dawes, P. R. 1976: Reconnaissance of Eocambrian and Lower Palaeozoic strata in south-western Peary Land, North Greenland. Rapp. Grønlands geol. Unders. 80, 9-14.

Jepsen, H. F. 1971: The Precambrian, Eocambrian and early Palaeozoic stratigraphy of the Jørgen Brønlund Fjord area, Peary Land, North Greenland. Bull. Grønlands geol. Unders. 96 (also Meddr Grønland 192,2) $42 \mathrm{pp}$.

O'Connor, B. 1979: The Portfjeld Formation (?early Cambrian) of eastern North Greenland. Rapp. Grønlands geol. Unders. 88, 23-28.

Palmer, A. R. \& Peel, J. S. 1979: New Cambrian faunas from Peary Land, eastern North Greenland. Rapp. Grønlands geol. Unders. 91, 29-36.

Peel, J. S. 1979: Cambrian - Middle Ordovician stratigraphy of the Adams Gletscher region, south-west Peary Land, North Greenland. Rapp. Grønlands geol. Unders. 88, 29-39.

Peel, J. S. 1980: Early Cambrian microfossils from the Portfjeld Formation, Peary Land, eastern North Greenland. Rapp. Grønlands geol. Unders. 100, 15-17.

Troelsen, J. C. 1949: Contributions to the geology of the area round Jørgen Brønlunds Fjord, Peary Land, North Greenland. Meddr Grønland 149(2), 29 pp.

Troelsen, J. C. 1956: The Cambrian of North Greenland and Ellesmere Island. In El sistema Càmbrico, su paleogeografía y el problema de su base. 20 Congr. geol. int. Mêxico. Symp. 3(1), 71-90. 